\title{
RESORCINOL COMPOUNDS ISOLATED FORM THE BARK OF MYRISTICA FATUA HOUTT
}

\author{
Research Center for \\ Chemistry, Indonesian \\ Institute of Sciences, \\ Kawasan PUSPIPTEK \\ Serpong, Kota Tangerang \\ Selatan, 15314, Indonesia \\ Submitted: 8-01-2017 \\ Revised: 10-03-2017 \\ Accepted: $12-04-2017$ \\ ${ }^{*}$ Corresponding author \\ Megawati \\ Email: \\ megarafandi@gmail.com
}

\author{
Megawati*, Akhmad Darmawan
}

\begin{abstract}
Myristica fatua Houtt. is one of the endemic plants growth in Wallace region. Isolation of the secondary metabolite compounds from the ethyl acetate fraction of the bark of Myristica fatua Houtt. has been done using some chromatography techniques afforded two resorcinol compounds, malabaricone C (1), and malabaricone B (2). The structures of 1-2 were determined using spectroscopic techniques, including mass spectrometry, 1D-NMR and 2D-NMR. Both compounds showed in vitro cytotoxic activity against the breast carcinoma cancer cell lines MCF-7 using alamar blue assay method, with $\mathrm{IC}_{50}$ of 2.38 and $0.71 \mu \mathrm{g} / \mathrm{mL}$, respectively.
\end{abstract}

Key words: Myristica fatua Houtt., resorcinol, malabaricone $B$, malabaricone $C$, cytotoxic

\section{INTRODUCTION}

Myristica (Myristicaceae) widely distributed from India and South East Asia to North Australia and the Pacific Islands.Myristica comprising of 72 species, and one of them is Myristica fatua Houtt (Zachariah, 2008). M. fatua is endemic to the Kalimantan, Sulawesi, Moluccas in Indonesia, beside the other region such as India, Philippines, New Guinea, Solomon Island, Pacific Islands, and New Caledonia. Mekongga forest is a conservation forest in Kolaka District, Northeast Sulawesi, Indonesia, which have so many uniques and endemic bioresources (Lim, 2012).

Lignans and acylphenols are the secondary metabolites major compound produced by this family (Nemethy, 1986; Woo, 1987; Cooray, 1987; Kumar, 1988; Hada, 1988; Nakatani, 1988; Herath, 1996; Herath, 1997; Pham, 2000\& 2002; Talukdar, 2000; Calliste, 2010; Cuong, 2011; Chong, 2011; Manjunatha, 2011; Ragasa, 2013; Cao, 2013; Cao, 2015; Acuna, 2016; Wahab, 2016; Pandey, 2016; Sivasothy, 2016). In addition to their activities of antioxidant, antibacterial, antimicrobial, nematocide, and cytotoxic (Pham, 2000; Talukdar, 2000; Pham, 2002), antiinflammatory (Cuong, 2011; Cao, 2013; Cao, 2015), anxiogenic (Sonavane, 2002), antihelmintic (Lopez, 2015), cholinesterase inhibitor (Wahab, 2016), terapeutic (Jangid, 2014), acylphenols also been known to have alpha-glucosidase inhibitor activity (Sivasothy, 2016).

There is no reported study on $M$. fatua, except a study for antioxidant and antibacterial activities (Viveka, 2016) and its potency as $\alpha$ glucosidase inhibitor (Sivasothy, 2016). It is encourages us to do a phytochemical study about secondary metabolite compounds contained in Myristica fatua Houtt. In this paper we will describe the isolation of the acylphenols from $M$. fatua, the structure of malabaricone B (1) and $C(2)$, and their cytotoxic activity against breast carcinoma MCF-7 cell lines.

\section{MATERIALS AND METHODS \\ General.}

The 1D- and 2D-NMR spectra were recorded by JEOL JNM-ECA 500 spectrometer with $\mathrm{CD}_{3} \mathrm{OD}$ as a solvent and TMS as an internal standard. LC-ESI-MS were measured by the Mariner Biospectrometry-Finnigan instrument with methanol p.a (Merck) as a solvent. Column chromatography was performed using silica gel (200-300 mesh, Kieselgel 60, E. Merck) as stationary phase.

\section{Plant material.}

The bark of Myristica fatua were collected from the Mekongga Forest, District of Kolaka, Southeast Sulawesi, Indonesia. The plant was determined and deposite as a specimen in Herbarium Bogoriense, Research Centre for 
Biology, Indonesian Institute of Sciences, Cibinong-Bogor, Indonesia.

\section{Extraction and isolation}

Dried and powdered bark of $M$. fatua $1.5 \mathrm{k} \mathrm{g}$ were macerated in methanol, evaporated using rotary evaporator to get $41.9 \mathrm{~g}$ methanol crude extract. Methanol soluble fraction ( $20 \mathrm{~g}$ ) was column chromatographed over silica gel and eluted with a gradient solvent system of $n$-hexane:EtOAc to obtain 10 fractions (F1- F10). Fraction 5(F5) further sephadex chromatographed using methanol: dichloromethane (1:1) as system solvent to give 7 sub-fraction (SF1-SF7). Compound 1 (20mg) and $2(30 \mathrm{mg})$ was crystallized from sub-fraction 5.4 (SF-5.4) and sub-fraction 5.5 (SF-5.5), respectively. Chemical structure identification of compound 1 and 2 performed with liquid chromatography-mass spectroscopy (LC-MS) and 1D- and 2D-nuclear magnetic resonance (NMR).

Compound 1: Malabaricone C, ESI-MS $\mathrm{m} / \mathrm{z} 359$ [M+H]; NMR (JEOL JNM-ECA 500) $\delta_{\mathrm{H}}\left(500 \mathrm{MHz}\right.$, in $\left.\mathrm{CD}_{3} \mathrm{OD}\right): 6.33(2 \mathrm{H}, \mathrm{d}, J 8.43$ $\mathrm{Hz}, \mathrm{H}-18 / 20), 7.19$ (1H, t, J 8.43 \& $7.79 \mathrm{~Hz}, \mathrm{H}-$ 19), $6.46(1 \mathrm{H}, \mathrm{dd}, J 2.60 \& 1.95 \mathrm{~Hz}, \mathrm{H}-15), 6.59$ $(1 \mathrm{H}, \mathrm{d}, J 1.95, \mathrm{H}-11), 6.64(1 \mathrm{H}, \mathrm{d}, J 7.79 \mathrm{~Hz}, \mathrm{H}-$ 14), 3.11 (2H, t, H-2), 1.66 (2H, p, H-3), 1.33 (8H, br.s, H-4/5/6/7), 1.55 (2H, m, H-8), 2.44 $(2 \mathrm{H}, \mathrm{t}, \mathrm{H}-9) . \delta_{\mathrm{C}}\left(125 \mathrm{MHz}\right.$, in $\left.\mathrm{CD}_{3} \mathrm{OD}\right): 45.7$ (C-2), 25.6 (C-3), 30.4 (C-4), 30.6 (2C, C-5/7), 30.7 (C-6), 33.1 (C-8), 36.4 (C-9), 135.8 (C-10), 116.6 (C-11), 146.1 (C-12), 144.1 (C-13), 116.3 (C-14), 120.7 (C-15), 111.5 (C-16), 163.5 (2C, C-17/21), 108.4 (2C, C-18/20), 136.9 (C-19), $209.5(\mathrm{C}-1, \mathrm{C}=\mathrm{O})$.

Compound 2: Malabaricone B, ESI-MS $\mathrm{m} / \mathrm{z} 342$ [M+H]; NMR (JEOL JNM-ECA 500) $\delta_{\mathrm{H}}\left(500 \mathrm{MHz}\right.$, in $\left.\mathrm{CD}_{3} \mathrm{OD}\right): 6.33(2 \mathrm{H}, \mathrm{d}, J 8.43$ $\mathrm{Hz}, \mathrm{H}-18 / 20), 7.19(1 \mathrm{H}, \mathrm{t}, J 8.43$ \& $8.45 \mathrm{~Hz}, \mathrm{H}-$ 19), $6.96(2 \mathrm{H}, \mathrm{d}, J 8.43 \mathrm{~Hz}, \mathrm{H}-11 / 15), 6.67(2 \mathrm{H}$, d, J $8.43 \mathrm{~Hz}, \mathrm{H}-12 / 14), 3.11$ (2H, t, H-2), 1.66 (2H, p, H-3), 1.33 (8H, br.s, H-4/5/6/7), 1.55 (2H, p, H-8), 2.44 (2H, t, H-9). $\delta_{\mathrm{C}}(125 \mathrm{MHz}$, in $\left.\mathrm{CD}_{3} \mathrm{OD}\right): 45.7$ (C-2), 25.6 (C-3), 30.4 (C-4), 30.6 (2C, C-5/7), 30.7 (C-6), 33.1 (C-8), 36.4 (C-9), 135.8 (C-10), 130.2 (2C-11/15), 116.0 (2C, C12/14), 156.3 (C-13), 111.5 (C-16), 163.5 (2C, C-17/21), 108.3 (2C, C-18/20), 136.8 (C19), 209.8 (C-1, C=O)

\section{Cancer cells line preparations}

In this study, we used breast carcinoma (MCF-7) cells line as cancer cells. Cancer cell was cultured at $37^{\circ} \mathrm{C}$ of temperature with $95 \%$ moisture content and $5 \% \mathrm{CO}_{2}$ in DME medium contained $10 \%$ of FBS for 3 days (until the cell cultures undergo confluent 60$70 \%$ ). Removed and replace the medium with a new medium and continued the incubation for next 24h. Wash Cultured cells with PBS 1-2 times and suspended using trypsin-EDTA solution.

\section{Cytotoxic assay}

Cytotoxic assay carried out using Alamar Blue method(Alamar Blue Assay, U.S. Patent No.5,501,959). $100 \mu \mathrm{L}$ of cells line was supplemented with $10 \mu \mathrm{L}$ of samples, incubated at temperature $37^{\circ} \mathrm{C}$ for $24 \mathrm{~h}$. The coloring process was done through the addition of Alamar blue solution for $4 \mathrm{~h}$. The color intensity of the cells line was measured by using ELISA plate reader at 560nm (excitation) and 590nm (emission). Percent viability is calculated using the formula as follows:

\section{$\frac{\mathrm{OD}(\text { cell }+ \text { sample) }-\mathrm{OD}(\text { negative controh) }}{\mathrm{OD}(\text { cells })-\mathrm{OD} \text { (negative control) }} \times 100=\%$ viability}

While $\mathrm{IC}_{50}$ of the active samples was calculated using linear regression analysis between percent of survival against the concentration of the sample

\section{RESULTS AND DISCUSSION}

Compound $\mathbf{1}$ was isolated as yellowish brown crystals, its has positive ESI-MS $[\mathrm{M}+\mathrm{H}]+$ at $\mathrm{m} / \mathrm{z}$ 359. ${ }^{1} \mathrm{H}-\mathrm{NMR}$ data showed that compound 1 has 6 aromatic protons at $\delta$ 6.46, 6.64, 6.59 in 1st aromatic ring, $6.33(2 \mathrm{H})$, 7.19 in 2 nd aromatic ring and 8pair of methylene proton groups at $\delta 3.11,1.66,1.33$ $\left(4-\mathrm{CH}_{2}\right), 1.55$, and 2.44 . Three proton peaks at $\delta 6.46(1 \mathrm{H}, \mathrm{dd}, J 2.60 \& 1.95 \mathrm{~Hz}), 6.59(1 \mathrm{H}, \mathrm{d}, J$ $1.95 \mathrm{~Hz}), 6.64(1 \mathrm{H}, \mathrm{d}, J 7.79 \mathrm{~Hz})$ in 1 st ring showed the AMX pattern of aromatic ring proton system, its mean that in 1st aromatic ring has 2 type of aromatic proton position: ortho position between $\delta 6.46$ and $\delta 6.64$, and meta position between $\delta \quad 6.46$ and $\delta \quad 6.59$ (Figure 1a). In addition, two proton peaks at $\delta$ $6.33(2 \mathrm{H}, \mathrm{d}, J 8.43 \mathrm{~Hz})$ and $7.19(1 \mathrm{H}, \mathrm{t}, J 8.43 \&$ 

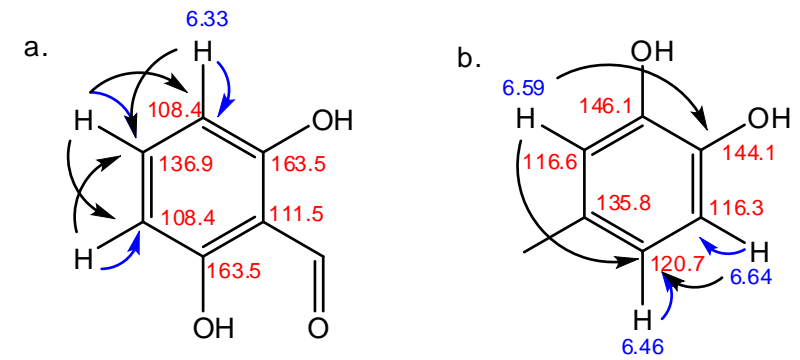

Figure 1. Proton pattern of the 1 st and 2 nd aromatic ring of Compound 1<smiles>O=C(CCCCCCCCc1ccccc1)c1ccccc1O</smiles>

Malabaricone C

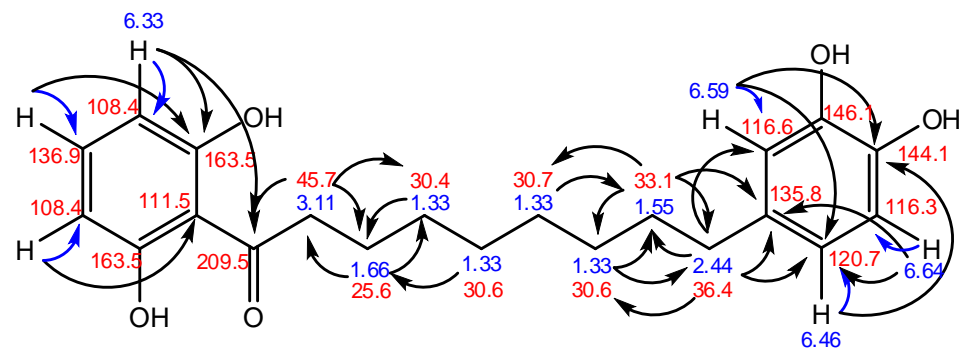

Figure 2. HMQC and HMBC correlations of compound 1

$7.79 \mathrm{~Hz}$ ) in 2 nd ring showed the $\mathrm{AB}_{2}$ pattern of aromatic ring proton system, indicated that $2 \mathrm{nd}$ aromatic ring has two symmetric proton peak at $\delta 6.33$, which has correlation with proton peak at $\delta 7.19$ in ortho position (Figure 1b). Two methylene proton peaks of compound $\mathbf{1}$ showed downfield chemical shift at $\delta 3.11$ and 2.44 indicated that their position were located close to the electronegatif atom or attached to aromatic ring. HMBC data (Figure 2) showed that proton peak at $\delta 3.11$ has a correlation with carbonyl group at $\delta$ 209.5, and another proton peak ( $\delta$ 2.44) has three different correlations with three different carbon atom $(\delta$ $135.8 ; 120.7$; 116.6) from 2 nd aromatic ring.
${ }^{13} \mathrm{C}-\mathrm{NMR}$ data showed 18 peak of carbon atoms including a downfield carbonyl signal at $\delta 209.5$. Three carbon peaks at $\delta 30.6$, 108.4, and 163.5 showed higher intensity compared to other carbon peaks, indicated that compound 1 has three symmetric carbon atoms. Five sp2 methine carbon peaks can be observed at 108.4 (2C), 116.3, 116.6, 120.7, and 136.9, two quaternary sp2 carbon at $\delta 111.5$ and 135.8, and four oxyaryl carbons at $\delta 144.1$, 146.1, and $163.5(2 \mathrm{C})$.

The HMQC $\left(1 J_{(\mathrm{C}-\mathrm{H})}\right)$ and HMBC $\left({ }^{2} J_{(\mathrm{C}-\mathrm{H})}\right.$ to ${ }^{4}(\mathrm{C}-\mathrm{H})$ ) correlations of compound $\mathbf{1}$ (Figure 2). The HMQC correlation between a downfield proton atom at $\delta 3.11$ with a downfield methylene carbon atom at $\delta 45.7$ indicated that both atom were located near the electronegatif 


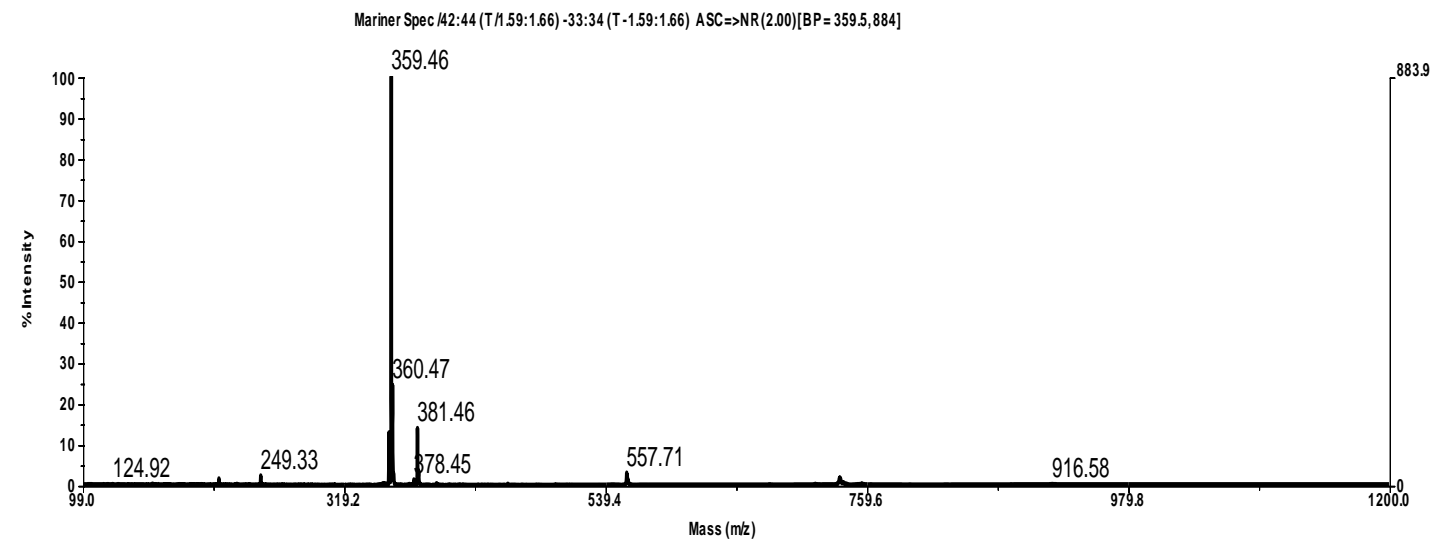

Figure 3. ESI-MS spectra of compound 1

a.

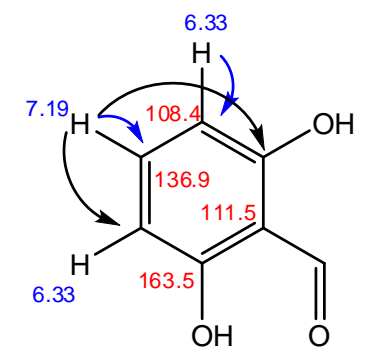

b.

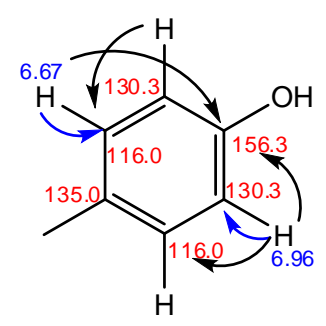

Figure 4. Proton pattern of the 1 st and 2 nd aromatic ring of Compound 2<smiles>O=C(CCCCCCCCc1cccc(O)c1)c1ccccc1O</smiles>

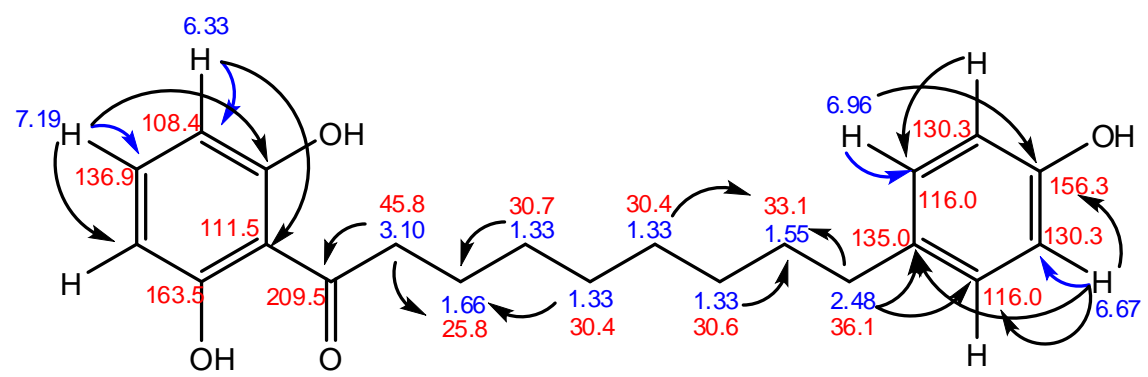

Figure 5. HMQC and HMBC correlations of compound 2 


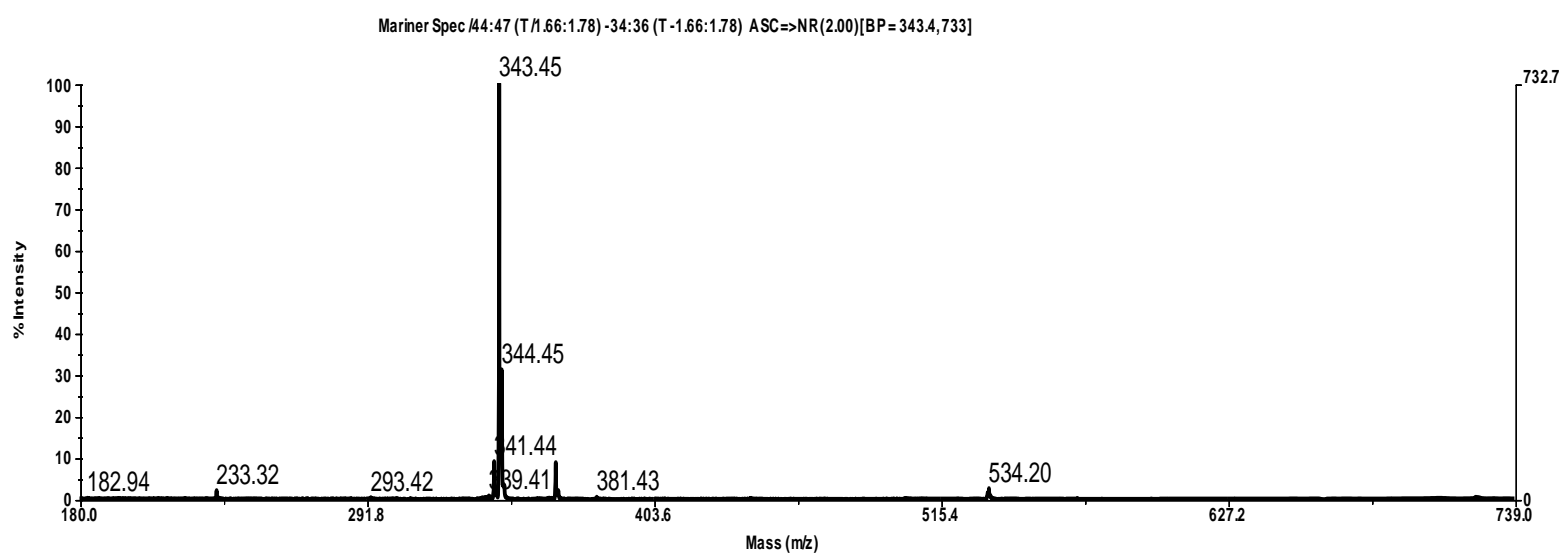

Figure 6. ESI-MS spectra of compound 2

Tabel I. ${ }^{13} \mathrm{C}$ - and ${ }^{1} \mathrm{H}-\mathrm{NMR}$ date for malabaricone $\mathrm{C}(1)\left({ }^{1} \mathrm{H}: 500 \mathrm{MHz},{ }^{13} \mathrm{C}: 125 \mathrm{MHz}\right.$, in $\mathrm{CD}_{3} \mathrm{OD}$; carbon numbering does not follow the official rule and is used here for simplicity)

\begin{tabular}{|c|c|c|c|c|}
\hline & \multicolumn{2}{|r|}{1} & \multicolumn{2}{|c|}{ Malabaricone C (Pham, 2000) } \\
\hline & $\delta_{\mathrm{C}}$ & $\delta_{\mathrm{H}}(\mathrm{m}, J(\mathrm{~Hz}))$ & $\delta_{\mathrm{C}}$ & $\delta_{\mathrm{H}}(\mathrm{m}, J(\mathrm{~Hz}))$ \\
\hline 1 & 209.5 & & 208.7 & \\
\hline 2 & 45.7 & $3.11(\mathrm{t})$ & 44.6 & $3.09(\mathrm{t})$ \\
\hline 3 & 25.6 & $1.66(\mathrm{p})$ & 24.3 & $1.62(\mathrm{p})$ \\
\hline 4 & 30.4 & 1.33 (br.s) & 29.2 & $1.30(\mathrm{~m})$ \\
\hline 5 & 30.6 & & 29.2 & 1.26 (br.s) \\
\hline 6 & 30.7 & & 29.2 & \\
\hline 7 & 30.6 & & 28.9 & \\
\hline 8 & 33.1 & $1.55(\mathrm{~m})$ & 31.4 & $1.49(\mathrm{p})$ \\
\hline 9 & 36.4 & $2.44(\mathrm{t})$ & 35.0 & $2.39(\mathrm{t})$ \\
\hline 10 & 135.8 & & 135.3 & \\
\hline 11 & 116.6 & $6.59(\mathrm{~d}, 1.95)$ & 115.2 & $6.62(\mathrm{~d}, 2.0)$ \\
\hline 12 & 146.1 & & 143.8 & \\
\hline 13 & 144.1 & & 141.8 & \\
\hline 14 & 116.3 & $6.64(\mathrm{~d}, 7.79)$ & 114.9 & $6.67(\mathrm{~d}, 8.0)$ \\
\hline 15 & 120.7 & $6.46(\mathrm{dd}, 2.60 \& 1.95)$ & 120.0 & $6.50(\mathrm{dd}, 2.0 \& 8.0)$ \\
\hline 16 & 111.5 & & 110.1 & \\
\hline 17 & 163.5 & & 161.8 & \\
\hline 18 & 108.4 & $6.33(\mathrm{~d}, 8.43)$ & 107.5 & $6.31(\mathrm{~d}, 8.1)$ \\
\hline 19 & 136.9 & $7.19(\mathrm{t}, 8.43 \& 7.79)$ & 135.7 & $7.12(\mathrm{t}, 8.1)$ \\
\hline 20 & 108.4 & $6.33(\mathrm{~d}, 8.43)$ & 107.5 & $6.31(\mathrm{~d}, 8.1)$ \\
\hline 21 & 163.5 & & 161.8 & \\
\hline
\end{tabular}

atom, were supported by the HMBC correlation between proton atom at $\delta 3.11$ with carbonyl group at $\delta 209.5$, the same things happen to methylene group at $\delta_{\mathrm{H}} 1.66 / \delta_{\mathrm{C}} 25.6$. Other HMBC correlations between a downfield proton atom at $\delta 2.44$ with carbon quaternary sp2 (1st aromatic ring) at $\delta 135.8$ showed the influence of the aromatic ring to the chemical shift value of the carbon atom at $\delta 36.4$. The ESI-MS spectra (Figure 3) showed a molecular ion $[\mathrm{M}+\mathrm{H}]^{+} \quad 359.46$ or $[\mathrm{M}+] \quad 358.46$, corresponds to molecular formula $\mathrm{C}_{21} \mathrm{H}_{26} \mathrm{O}_{5}$. 
Tabel II. ${ }^{13} \mathrm{C}$ - and ${ }^{1} \mathrm{H}-\mathrm{NMR}$ data for malabariconesB (2) $\left({ }^{1} \mathrm{H}: 500 \mathrm{MHz},{ }^{13} \mathrm{C}: 125 \mathrm{MHz}\right.$, in $\mathrm{CD}_{3} \mathrm{OD}$; carbon numbering does not followthe official rule and is used here for simplicity)

\begin{tabular}{ccccc}
\hline & & $\mathbf{2}$ & \multicolumn{2}{c}{ Malabaricone B (Pham, 2000) } \\
\cline { 2 - 5 } & $\boldsymbol{\delta}_{\mathbf{C}}$ & $\boldsymbol{\delta}_{\mathbf{H}}(\mathbf{m}, \boldsymbol{J}(\mathbf{H z}))$ & $\boldsymbol{\delta}_{\mathbf{C}}$ & $\left.\boldsymbol{\delta}_{\mathbf{H}}(\mathbf{m}, \boldsymbol{J} \mathbf{( H z})\right)$ \\
\hline 1 & 209.8 & & 208.6 & \\
2 & 45.7 & $3.11(\mathrm{t})$ & 44.7 & $3.10(\mathrm{t})$ \\
3 & 25.6 & $1.66(\mathrm{p})$ & 24.4 & $1.64(\mathrm{p})$ \\
4 & 30.4 & $1.33(\mathrm{br} . \mathrm{s})$ & 29.5 & $1.29(\mathrm{br} . \mathrm{s})$ \\
5 & 30.6 & & 29.0 & \\
6 & 30.7 & & 29.0 & \\
7 & 30.6 & & 29.2 & $1.51(\mathrm{p})$ \\
8 & 33.1 & $1.55(\mathrm{~m})$ & 31.6 & $2.46(\mathrm{t})$ \\
9 & 36.4 & $2.44(\mathrm{t})$ & 35.0 & \\
10 & 135.8 & & 134.6 & $6.96(\mathrm{~m}, 8.4)$ \\
11 & 130.2 & $6.96(\mathrm{~d}, 8.43)$ & 129.3 & \\
12 & 116.0 & $6.67(\mathrm{~d}, 8.43)$ & 115.0 & $6.69(\mathrm{~m}, 8.4)$ \\
13 & 156.3 & & 153.6 & $6.96(\mathrm{~m}, 8.4)$ \\
14 & 116.0 & $6.67(\mathrm{~d}, 8.43)$ & 115.0 & \\
15 & 130.2 & $6.96(\mathrm{~d}, 8.43)$ & 129.3 & $6.32(\mathrm{~d}, 8.2)$ \\
16 & 111.5 & & 110.1 & $7.14(\mathrm{t}, 8.2)$ \\
17 & 163.5 & & 161.6 & $6.32(\mathrm{~d}, 8.2)$ \\
18 & 108.3 & $6.33(\mathrm{~d}, 8.43)$ & 107.8 & \\
19 & 136.8 & $7.19(\mathrm{t}, 8.43)$ & 135.7 & \\
20 & 108.3 & $6.33(\mathrm{~d}, 8.43)$ & 107.8 & \\
21 & 163.5 & & 161.6 & \\
\hline
\end{tabular}
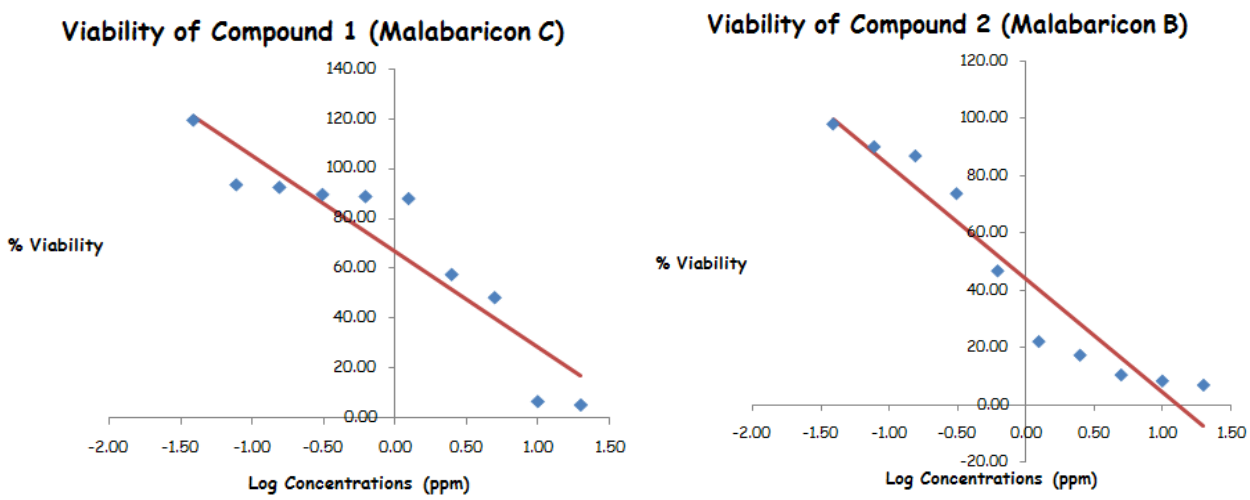

Figure 7. Viability plots of compound 1 and compound 2 against breast carcinoma (MCF-7) cells line.

Based on the NMR data, supported by ESI-MS data and reference (Table I), compound 1 was identified as malabaricone C (Figure 2)(Pham, 2000).

Compound 2 was isolated as yellowish brown, its has positive ESI-MS $[\mathrm{M}+\mathrm{H}]+\mathrm{at} \mathrm{m} / \mathrm{z}$ 343. ${ }^{1} \mathrm{H}-\mathrm{NMR}$ data showed that compound 2 has 7 aromatic proton at $\delta 6.33(2 \mathrm{H}), 7.19$ in ${ }^{1}$ st aromatic ring, $6.96(2 \mathrm{H}), 6.67(2 \mathrm{H})$ in ${ }^{2} \mathrm{nd}$ aromatic ring and 8 pair of methylene proton groups at $\delta 3.10,1.66,1.33\left(4-\mathrm{CH}_{2}\right), 1.55$, and 2.49. Two proton peaks at $\delta 6.67(2 \mathrm{H}, \mathrm{d}, J 8.43$ $\mathrm{Hz})$ and $6.96(2 \mathrm{H}, \mathrm{d}, J 8.43 \mathrm{~Hz})$ in 1st ring indicated the presence of AA'XX' pattern 
of aromatic ring proton system, its mean that in 1st aromatic ring has four symmetric proton peaks with one type of ortho aromatic proton position at $\delta 6.96$ and 6.67 (Figure 4a). In addition, two proton peaks at $\delta 6.33(2 \mathrm{H}, \mathrm{d}$, $J 8.43 \mathrm{~Hz})$ and $7.19(1 \mathrm{H}, \mathrm{t}, J 8.43 \mathrm{~Hz})$ in $2 \mathrm{nd}$ ring showed the $\mathrm{AB}_{2}$ pattern of aromatic ring proton system(Figure 4b), indicated that 2 nd aromatic ring has two simetris proton peak at $\delta$ 6.33 , which has correlation with proton peak at $\delta 7.19$ in ortho position. Both $\mathrm{AA}^{\prime} \mathrm{XX}$ ' and $\mathrm{AB}_{2}$ patterns were supported by HMQC and HMBC correlation data (Figure 5). ${ }^{13} \mathrm{C}-\mathrm{NMR}$ data showed 16 peak of carbon atoms including a downfield carbonyl signal at $\delta$ 209.8. Five carbon peaks at $\delta 30.6,108.4,116.0,130.3$, and 163.5 showed higher intensity compared to other carbon peaks, indicated that compound 2 has five simetris carbon atoms. Seven $\mathrm{sp}^{2}$ methine carbon peaks can be observed at 108.4 (2C), 116.0 (2C), 130.3 (2C), and 136.9, two quaternary sp2 carbon at $\delta 111.5$ and 135.0, and three oxyaryl carbons at $\delta 156.3$, and 163.5(2C).

The HMQC $\left({ }^{1} J_{(\mathrm{C}-\mathrm{H})}\right)$ and HMBC $\left({ }^{2} J_{(\mathrm{C}-\mathrm{H})}\right.$ to ${ }^{4}(\mathrm{C}-\mathrm{H})$ ) correlations of compound 2 illustrated in Figure 5. The HMQC correlation between a downfield proton atom at $\delta 3.10$ with a downfield methylene carbon atom at $\delta 45.8$ indicated that both atom were located near the electronegatif atom, were supported by the HMBC correlation between proton atom at $\delta$ 3.10 with carbonyl group at $\delta 209.8$, the same things happen to methylene group at $\delta_{\mathrm{H}}$ $1.66 / \delta_{C}$ 25.8. Other HMBC correlation between a downfield proton atom at $\delta 2.49$ with carbon quaternary sp2 (1st aromatic ring) at $\delta 135.0$ showed the influence of the aromatic ring to the chemical shift value of the carbon atom at $\delta$ 36.1. The ESI-MS spectra (Figure 6) showed a molecular ion $[\mathrm{M}+\mathrm{H}]+343.45$ or $[\mathrm{M}+] 342.45$ indicates the molecular weight of the compound corresponds to molecular formula $\mathrm{C}_{21} \mathrm{H}_{26} \mathrm{O}_{4}$.

Based on the NMR data, supported by ESI-MS data and reference (Table II), compound 2 was identified as malabaricone B (Figure 5) (Pham, 2000).

\section{Cytotoxic assay}

Compound 1-2 were examined for their cytotoxicity against the breast carcinoma (MCF-7) cells line (Figure 7) and showed that both compounds were active as anticancer compounds against breast carcinoma (MCF-7) cells line with the $\mathrm{IC}_{50}$ values 2.68 and $0.71 \mu \mathrm{g} / \mathrm{mL}$, respectively.

\section{CONCLUSION}

Isolation and purification of ethyl acetate fraction $5(\mathrm{~F}-5)$ of the bark of $M$. fatua using column chromatography method, and structure elucidation based on spectroscopic data analysis result have been done. Can be concluded that compound $\mathbf{1}$ and $\mathbf{2}$ are malabaricone $\mathrm{C}$ and malabaricone $\mathrm{B}$, respectively. Both compounds have high cytotoxicity activity against breast carcinoma (MCF-7) cells line with $\mathrm{IC}_{50}$ values are 2.68 and $0.71 \mu \mathrm{g} / \mathrm{mL}$, respectively.

\section{ACKNOWLEDGEMENTS}

We thanks to Mrs. Puspa Dewi N. Lotulung, M.Eng for the mass spectra, Dr. Linar Z. Udin for the cytotoxicity bioassay, Dr. Rizna Triana Dewi and Mrs. Sofa Fajriah, M.Si. for the interesting discussion, and to the Indonesian Institute of Sciences for funding our research project.

\section{REFERENCES}

Calliste CA., Kozlowski D.,Duroux JL., Champavier Y., Chulia AJ., Trouillas P., 2010. A new antioxidant from wild nutmeg.Food Security 118: 489-496.

Chong YM., Yin WF., Ho CY., Mustafa MR., Hadi AHA., Awang K., Narrima P., Koh C-L., Appleton DR., Chan K-G., 2011.Malabaricone C from Myristica cinnamomea exhibits anti-quorum sensing activity. J. Nat. Prod. 74: 2261-2264.

Cooray NF., Jansz ER., Wimalasena S., Wijesekera TP., Nair BM., 1987. Acylresorcinols from seed kernels of Myristica dactyloides.Phytochemistry, 26(12): 3369-3371.

Cuong TD., Hung TM., Na MK., Ha DT., Kim JC., Lee D., Ryoo SW., Lee JH., Choi JS., Min BS., 2011. Inhibitory effect on NO production of phenolic compounds 
from Myristica fragrans.Bioorg. Med. Chem. Lett. 21: 6884-6887.

Zachariah TJ., Leela NK., Maya KM., Mathew PA., Vipin TM., Krishnamoorthy B., 2008. Chemical composition of leaf oils of Myristica beddomeii (King), Myristica fragrans (Houtt.) and Myristica malabarica (Lamk.).J. of Spices and Aromatic Crops. 17(1): 10-15

Lim TK. 2012. Edible Medicinal And NonMedicinal Plants: Volume 3, Fruits. Springer Netherlands. pp.572-574.

Nemethy EK., Lago R., Hawkins D., Calvin M., 1986. Lignans of Myristica otoba.Phytochemistry, 25(4): 959-960.

Woo WS., Shin KH., Wagner H., Lotter H., 1987. The structure of macelignan from Myristica fragrans. Phytochemistry, 26(5): 1542-1543.

Kumar NS., Herath HMWB., Karunaratne V., 1988. Arylalkanones from Myristica dactyloides.,Phytochemistry, 27(2): 465-468.

Hada S., Hattori M., Tezuka ., Kikuchi T., Namba T., 1988. New neolignans and lignans from the aril of Myristica fragrans. Phytochemistry, 27(2): 563-568.

Nakatani N., Ikeda K., Kikuzaki H., Kido M., $\begin{array}{lll}\text { Yamaguchi Y., } & 1988 .\end{array}$ Diaryldimethylbutane lignans from Myristica argentea and their antimicrobial action against Streptococcus mutans. Phytochemistry, 27(10): 3127-3129.

Herath HMTB., Priyadarshin AMA., 1996. Two lignans and an aryl alkanone from Myristica dactyloides. Phytochemistry, 42(5): 1439-1442.

Herath HMTB., Priyadarshin AMA., 1997. Lignans from Myristica dactyloides. Phytochemistry, 44(4): 699-703.

Pham VC., Jossang A., Sevenet T.,, Bodo B., 2000. Cytotoxic acylphenols from Myristica maingayi.Tetrahedron, 56: $1707-$ 1713.

Talukdar AC., Jain N., De S., KrishnamurtyH.G., 2000. H.G. Phytochemistry, 53: 155-157.

Pham VC., Jossang A.,, Sevenet T., Bodo B., 2002. Novel cytotoxic acylphenol dimers of Myristica gigantea; enzymantic synthesis of giganteones A and B.Tetrahedron, 58: 5709-5714.
Manjunatha BK., Mankani KL., Mukunda SK., Divakara R., Sridar BK., Paul K., 2011. Antioxidant and hepato protective effect of Myristica malabarica seed aril extracts on carbon tetrachloride induced hepatic damage.Global J. Biotech. Biochem., 6(1): 25-30.

Ragasa CY., Torres OB., Tongco JVV., Razal RA., Shen C-C., 2013. Resorcinols from Myristica philippensis Lam. J. Chem. Pharm. Res., 5(11): 614-616.

Cao G-Y., Yang X-W., Xu W., Li F., 2013.New inhibitors of nitric oxide production from the seeds of Myristica fragrans. Food Chem. Toxicol., 62: 167-171.

Cao G-Y., Xu W., Yang X-W., Gonzales FJ., Li F., 2015.New neolignans from the seeds of Myristica fragrans that inhibit nitric oxide production.Food Chem. 173: 231237.

Acuna UM., Carcache PJB., Matthew S., de Blanco EJC., 2016.New acyclic bis phenylpropanoid and neolignans, from Myristica fragrans Houtt., exhibiting PARP-1 and $\mathrm{NF}_{-\mathrm{K}} \mathrm{B}$ inhibitory effects. Food Chem. 202: 269-275.

Wahab SMA., Sivasothy Y., Liew SY., Litaudon M., Mohamad J., Awang K., 2016.Natural cholinesterase inhibitors from Myristica cinnamomea King. Bioorg. Med. Chem. Lett., 26: 3785-3792.

Pandey R., Mahar R., Hasanain M., Shukla SK., Sarkar J., Rameshkumar KB.,Kumar B., 2016.Rapid screening and quantitative determination of bioactive compounds from fruit extracts of Myristica species and their in vitro antiproliferative activity. Food Chem. 211:k' 486-493.

Sivasothy Y., Yong L.K., Hoong L.K., Litaudon M., Awang K., 2016.A potent alpha-glucosidase inhibitor from Myristica cinnamomea King. Phytochemistry, 122: 265269.

Gupta AD., Bansal VK., Babu V., Maithil N., 2013.Chemistry, antioxidant and antimicrobial potential of nutmeg (Myristica fragrans Houtt.). J. Gen. Eng. Biotech. 11: 25-31.

Chung JY., Choo JH., Lee MH., Hwang JK., 2006. Anticariogenic activity of macelignan isolated from Myristica 
fragrans (nutmeg) against Streptococcus mutans. Phytomedicine, 13: 261-266.

Olaleye MT., Akinmoladun AC., Akindahunsi AA., 2006.Antioxidant properties of Myristica fragrans (Houtt) and its effect on selected organs of albino rats. African J. Biotech. 5: 1274-1278.

Shazia M., Saba M., Jasmine F., Farhan K., Huma M., 2015.Anti-bacterial, antioxidant and cytotoxic potential of various extracts of Myristica fragrans. Int. J. Res. Ayurveda Pharm. 6(5): 643-648.

Viveka MR., Chandrashekar KR., 2016.Antioxidant and antibacterial activities ofMyristica fatua var. Magnifica (Beddome) Sinclair. Asian J. Pharm. Clin. Res. 9(4): 235-239.
Sonavane GS., Sarveiya VP., Kasture VS.,. Kasture SB., 2002. Anxiogenic activity of Myristica fragrans seeds. Pharm. Biochem. Behav. 71: 239-244.

Lopez V., Gerique J., Langa E., Berzosa C., Valero MS., Gomez-Rincon C., 2015.Antihelmintic effects of nutmeg (Myristica fragrans) on Anisakis simplex L3 larvae obtained from Micromesistius potassou.Res. Vet. Sci. 100: 148-152.

Jangid K., Jayakumar ND., Varghese SS., 2014. Achievable therapeutic effects of Myristica fragrans (nutmeg) on periodontitis A short review. Int. J. Pharm. Pharmaceutic. Sci. 6(5): 591-594. 